\title{
Aa. Vv., Actes du colloque Les grandes peurs 2. L'Autre, 30 sett.-3 oct. 2003
}

\section{Rosa Galli Pellegrini}

\section{(2) OpenEdition}

12 Journals

\section{Edizione digitale}

URL: http://journals.openedition.org/studifrancesi/36741

DOI: 10.4000/studifrancesi.36741

ISSN: 2421-5856

\section{Editore}

Rosenberg \& Sellier

\section{Edizione cartacea}

Data di pubblicazione: 1 juillet 2005

Paginazione: 203

ISSN: 0039-2944

\section{Notizia bibliografica digitale}

Rosa Galli Pellegrini, «Aa. VV., Actes du colloque Les grandes peurs 2. L'Autre, 30 sett.-3 oct. 2003»,

Studi Francesi [Online], 145 (XLIX | I) | 2005, online dal 30 novembre 2015, consultato il 20 avril 2021

URL: http://journals.openedition.org/studifrancesi/36741 ; DOI: https://doi.org/10.4000/studifrancesi. 36741

Questo documento è stato generato automaticamente il 20 avril 2021.

\section{(c)}

Studi Francesi è distribuita con Licenza Creative Commons Attribuzione - Non commerciale - Non opere derivate 4.0 Internazionale. 


\title{
Aa. Vv., Actes du colloque Les grandes peurs 2. L'Autre, 30 sett.-3 oct. 2003
}

\author{
Rosa Galli Pellegrini
}

\section{NOTIZIA}

«Travaux de littérature», XVII, 2004, (Actes du colloque Les grandes peurs 2. L'Autre, 30 sett.-3 oct. 2003), pp. 556.

1 Tra i contributi di questo numero della rivista che rientrano nella nostra rassegna segnaliamo una lettura attenta e minuziosa del romanzo citato nel titolo di Sara воNомо, La mise en cuvre de la peur dans le roman d'aujourd'hui: "Rosie Carpe» de Marie NDiaye, pp. 217-229), che la porta a reperirvi elementi riconducibili al contesto della paura, mentre viene messo in evidenza il processo evolutivo della narrativa di Marie NDiaye, dai primi romanzi a quello analizzato.

2 Véronique montemont, Après le désastre: Celan, Perec, Duras, pp. 493-504, accomuna autori che hanno condiviso la sofferenza prodotta dalla Shoah definendo la loro scrittura come l'ancoraggio necessario per poter continuare a vivere.

3 Jean SAROCCHI, Camus et la peur des intellectuels français, pp. 505-517, parte dall'analisi di questo tema in Camus e dall'atteggiamento dello scrittore verso di esso per ricordarne gli echi e la successiva caduta nell'oblio a conclusione del problema algerino. 